\title{
ERRATA
}

\section{Culture and molecular-based profiles show shifts in bacterial communities of the upper respiratory tract that occur with age}

Jennifer C Stearns, Carla J Davidson, Suzanne McKeon, Fiona J Whelan, Michelle E Fontes, Anthony B Schryvers, Dawn ME Bowdish, James D Kellner and Michael G Surette

The ISME Journal (2015) 9, 1268; doi:10.1038/ismej.2015.49

Correction to: The ISME Journal (2015) 9, 1246-1259; doi:10.1038/ismej.2014.250; published online 9 January 2015

After the publication of this paper, it was noticed that the names were not spelled out in full as per the ISME Journal's style. The following is how the names should appear:
'Jennifer C Stearns, Carla J Davidson, Suzanne McKeon, Fiona J Whelan, Michelle E Fontes, Anthony B Schryvers, Dawn ME Bowdish, James D Kellner and Michael G Surette.'

The publishers would like to apologise for any inconvenience this may have caused. This change has now been implemented.

\section{Genomic potential for nitrogen assimilation in uncultivated members of Prochlorococcus from an anoxic marine zone}

Marcia Astorga-Eló, Salvador Ramírez-Flandes, Edward F DeLong and Osvaldo Ulloa

The ISME Journal (2015) 9, 1268; doi:10.1038/ismej.2015.52

Correction to: The ISME Journal (2015) 9, 1264-1267; doi:10.1038/ismej.2015.21; published online 20 February 2015

After the publication of this paper, an error was noticed in the sentences 'Phylogenetic analysis using the 16S-23S rRNA internal transcribed spacer region revealed that the AMZ-associated Prochlorococcus assemblages are mainly composed of two novel LL ecotypes (termed LL-V and LL-VI), which correspond to basal groups linking Prochlorococcus with marine Synechococcus (Lavin et al., 2010), the other dominant marine picocyanobacteria. However, no genomic or picocyanobacterium information exists for these AMZ lineages'. 'Picocyanobacteria' should be 'picocyanobacterium' and in the next sentence, picocyanobacterium should be 'physiological'.

The publishers would like to apologise for any inconvenience caused by this error. These changes have now been implemented in the paper. 